\title{
A Bioinspired Molybdenum Catalyst for Aqueous Perchlorate Reduction
}

Changxu Ren ${ }^{1}$, Peng Yang ${ }^{2}$, Jiaonan $\mathrm{Sun}^{3}$, Eric Y. Bi ${ }^{1,4}$, Jacob Palmer ${ }^{1}$, Mengqiang Zhu ${ }^{2}$, Yiying $\mathrm{Wu}^{3}$, and Jinyong $\mathrm{Liu}^{1 *}$

${ }^{1}$ Department of Chemical and Environmental Engineering, University of California, Riverside, CA 92521, United States.

${ }^{2}$ Department of Ecosystem Science and Management, University of Wyoming, Laramie, WY 82071, United States.

${ }^{3}$ Department of Chemistry, The Ohio State University, Columbus, OH 43210, United States.

${ }^{4}$ Martin Luther King High School, Riverside, CA 92508, United States.

10 *Correspondence to: jinyongl@ ucr.edu; Jinyong.liu101@ gmail.com.

\begin{abstract}
The detection of perchlorate $\left(\mathrm{ClO}_{4}^{-}\right)$on and beyond Earth requires $\mathrm{ClO}_{4}{ }^{-}$reduction technologies to support water purification and space exploration. However, the reduction of $\mathrm{ClO}_{4}{ }^{-}$usually entails either harsh conditions or multi-component enzymatic processes. We developed a 15 heterogeneous $\mathrm{Mo}-\mathrm{Pd} / \mathrm{C}$ catalyst from sodium molybdate to reduce aqueous $\mathrm{ClO}_{4}{ }^{-}$into $\mathrm{Cl}^{-}$with 1 atm $\mathrm{H}_{2}$ at room temperature. Upon hydrogenation by $\mathrm{H}_{2} / \mathrm{Pd}$, the reduced Mo oxide species and a bidentate nitrogen ligand (1:1 molar ratio) are transformed in situ into oligomeric Mo sites on the carbon support. The turnover number and frequency for oxygen atom transfer from $\mathrm{ClO}_{\mathrm{x}}{ }^{-}$ substrates reached 3850 and $165 \mathrm{~h}^{-1}$ on each Mo site. This simple bioinspired design yielded a robust water-compatible catalyst for the removal and utilization of $\mathrm{ClO}_{4}^{-}$.
\end{abstract}


Perchlorate $\left(\mathrm{ClO}_{4}^{-}\right)$is a pervasive water contaminant on Earth $(1,2)$ and a major salt component in the surface soil on Mars $(3,4)$. Because the uptake of $\mathrm{ClO}_{4}{ }^{-}$through water and food can cause thyroid gland malfunction, $\mathrm{ClO}_{4}^{-}$levels in the drinking water are regulated. NASA has also identified Martian $\mathrm{ClO}_{4}{ }^{-}$as both a potential hazard to humans and an oxygen source to supply exploration activities (5). However, $\mathrm{ClO}_{4}{ }^{-}$is highly inert, so that it is widely used for ionic strength adjustment in various chemical systems. The oxidizing power of $\mathrm{ClO}_{4}{ }^{-}$has been primarily utilized via rocket fuels or munitions (1). Here, we report on a simple yet highly active heterogeneous Mo-Pd catalyst that can reduce aqueous $\mathrm{ClO}_{4}^{-}$into $\mathrm{Cl}^{-}$with 1 atm $\mathrm{H}_{2}$ at room temperature.

Microbes can use $\mathrm{ClO}_{4}^{-}$for respiration (Fig. 1A) (6, 7). In the multifactor metalloenzyme system (Fig. 1B), a Mo co-factor biosynthesized from molybdate (8) and amino acid residues mediate the oxygen atom transfer (OAT) (9) from $\mathrm{ClO}_{4}^{-}(10)$. The $\mathrm{Mo}^{\mathrm{IV} / \mathrm{VI}}$ redox cycling (Fig. 1C) is sustained by the electron transfer from $\mathrm{H}_{2}$ or acetate via multiple Fe-S clusters, heme complexes, and electron shuttle compounds (11). Such complexity in biological systems challenges the design of an artificial $\mathrm{ClO}_{4}{ }^{-}$reduction system, especially in aqueous phase under ambient conditions. For example, $\mathrm{ClO}_{4}{ }^{-}$reduction by a Fe complex relied on hydrogen bonds in the secondary coordination sphere (Fig. 1D) and thus required the use of an anhydrous medium $(12,13)$. Furthermore, a singlefunction metal complex or isolated reductase needs special electron donors (e.g., methyl viologen, hydrazine, ferrocene, and phosphine) to sustain the redox cycle of the OAT metal $(12,14,15)$. Therefore, a robust catalyst that can reduce aqueous $\mathrm{ClO}_{4}{ }^{-}$with $\mathrm{H}_{2}$ is highly desirable $(16,17)$.

In our bioinspired design (Fig. 1F), $\mathrm{Pd} / \mathrm{C}$ is used as the catalyst platform. The porous carbon mimics the protein pocket of the enzyme that accommodates the OAT metal site. $\operatorname{The} \mathrm{Pd}^{0}$ nanoparticles simplify the enzymatic electron transfer chain by directly harvesting electrons from $\mathrm{H}_{2}$. Then the key task was to construct a highly active Mo site from molybdate $\left(\mathrm{Mo}^{\mathrm{VI}} \mathrm{O}_{4}{ }^{2-}\right)$, the 
same Mo source for the biosynthesized Mo co-factors (8). Polyoxometalates of aqueous molybdate (18) were readily adsorbed onto $\mathrm{Pd} / \mathrm{C}$ within $30 \mathrm{~min}$ (fig. S1). The resulting heterogeneous $\mathrm{MoO}_{x}-\mathrm{Pd} / \mathrm{C}$ showed rapid reduction of $\mathrm{ClO}_{3}{ }^{-}(19)$ but had negligible activity with $\mathrm{ClO}_{4}^{-}$. Hence, we sought to substantially enhance the OAT activity of surface Mo sites by incorporating an organic ligand. Because biomimetic thio-coordinated Mo complexes are typically water- and oxygen-sensitive, we attempted to prepare active Mo sites in situ by simultaneously adding molybdate and neutral nitrogen ligands $(L)$ in the water suspension of $\mathrm{Pd} / \mathrm{C}$ under $1 \mathrm{~atm} \mathrm{H}_{2}$. This simple strategy achieved highly active $\mathrm{ClO}_{4}{ }^{-}$reduction by a series of $(L) \mathrm{MoO}_{x}-\mathrm{Pd} / \mathrm{C}$ catalysts (Table 1, figs. S2 and S3).

In general, aromatic bidentate ligands led to significantly higher $\mathrm{ClO}_{4}{ }^{-}$reduction activities than amines and monodentate pyridines. Bipyridine (bpy) was superior to phenanthroline and other aromatic ligands containing an imidazoline or oxazoline half moiety (Table 1, entries 17-19). Ligands with steric hindrance on the ortho positions (Table 1, entries 8, 9, and 20) and with a strain on the bpy backbone (Table 1, entry 22 versus 21) resulted in low activities. Electron-donating groups on the para positions (20) further enhanced the activity. At ambient temperature and pressure, $\mathrm{ClO}_{4}{ }^{-}$reduction by the $\left[\left(\mathrm{NH}_{2}\right)_{2}\right.$ bpy $] \mathrm{MoO}_{x}-\mathrm{Pd} / \mathrm{C}$ catalyst (Table 1 , entry 6 ) outperformed all abiotic catalysts reported to date (table S1). The chlorine balance was closed by $\mathrm{ClO}_{4}{ }^{-}$and $\mathrm{Cl}^{-}$, indicating a negligible buildup of $\mathrm{ClO}_{\mathrm{x}}{ }^{-}$intermediates (Fig. 2A). The optimal molar ratio between $\left(\mathrm{NH}_{2}\right)_{2}$ bpy and Mo was 1:1 (Fig. 2B), and the optimal Mo content in the catalyst was $5 \mathrm{wt} \%$ (Fig. 2C). The reuse of the catalyst for ten times did not cause a noticeable loss of activity (Fig. 2D, fig. S4). During the $\mathrm{ClO}_{4}^{-}$reduction, the ratios of leached $\mathrm{Mo}$ and $\left(\mathrm{NH}_{2}\right)_{2}$ bpy into water were $<1.5 \%$ and $<0.2 \%$ of the total amount in the catalyst, respectively (Fig. 2E). The apparent $1^{\text {st }}$-order kinetics with $0.01-1 \mathrm{mM} \mathrm{ClO}_{4}^{-}$and $0^{\text {th }}$-order kinetics at $1-100 \mathrm{mM} \mathrm{ClO}_{4}^{-}$(figs. S5 and S6) support the 
Langmuir-Hinshelwood model for heterogeneous catalysis (See Supplementary Text for kinetic modeling and mass transfer analysis). Notably, a $0.2 \mathrm{~g} / \mathrm{L}$ loading of the catalyst reduced $99.99 \%$ of $100 \mathrm{mM} \mathrm{ClO}_{4}^{-}(\sim 10 \mathrm{~g} / \mathrm{L})$ within $48 \mathrm{~h}$ (fig. S5c). Due to the high oxidative stress caused by $\mathrm{ClO}_{\mathrm{x}}{ }^{-}$intermediates $(10,21)$, complete reduction of $100 \mathrm{mM} \mathrm{ClO}_{4}{ }^{-}$in water has not been reported by either microbial or abiotic systems. Assuming the Mo sites catalyzed the OAT with both $\mathrm{ClO}_{4}{ }^{-}$ and $\mathrm{ClO}_{\mathrm{x}}{ }^{-}$intermediates, the turnover number (TON) for the single batch and the initial turnover frequency $\left(\mathrm{TOF}_{0}\right)$ reached 3850 and $165 \mathrm{~h}^{-1}$, respectively, for each Mo atom.

While enzymes use amino acid residues to facilitate the reduction of metal-bound oxyanions $(10,22)$, the carbon-supported catalyst needs external protons to enable the reaction $(19,20)$. The optimal activity was afforded by $1 \mathrm{mM} \mathrm{H}^{+}\left(\mathrm{pH} 3.0\right.$ by $\left.\mathrm{H}_{2} \mathrm{SO}_{4}\right)$. The reduced performance at a lower $\mathrm{pH}(\mathrm{Fig}$. 2F) was probably caused by the protonation of amino groups on $\left(\mathrm{NH}_{2}\right)_{2}$ bpy. In the presence of $0.1 \mathrm{M} \mathrm{Cl}^{-}, 2.0 \mathrm{M} \mathrm{Cl}^{-}$, and $1.0 \mathrm{M} \mathrm{SO}_{4}{ }^{2-}$, the catalyst retained $57 \%$, $5 \%$, and 36\% of activity, respectively (fig. S7 and table S2), showing promise for the reduction of $\mathrm{ClO}_{4}{ }^{-}$in brine solutions produced from ion-exchange or from reverse osmosis for water treatment (1). Furthermore, exposing the catalyst suspension to air did not cause irreversible deactivation. The same $\mathrm{ClO}_{4}{ }^{-}$reduction activity was recovered after resuming $\mathrm{H}_{2}$ supply (fig. S8a), suggesting that the in situ prepared catalyst can be handled in air. In comparison, the $\mathrm{Re}-\mathrm{Pd} / \mathrm{C}$ catalyst using the pre-synthesized $\mathrm{Re}^{\mathrm{V}}$ precursor (Fig. 1E) (23) was highly sensitive to air and would irreversibly deactivate (fig. S8b) $(24,25)$.

X-ray photoelectron spectroscopy (XPS) characterization identified the reduction of $\mathrm{Mo}^{\mathrm{VI}}$ precursor into multiple oxidation states $(+\mathrm{VI},+\mathrm{V},+\mathrm{IV},+\mathrm{III}$ and $+\mathrm{II})($ Fig. 3A versus $3 \mathrm{~B})$. Air exposure reoxidized the low-valent species to $\mathrm{Mo}^{\mathrm{V}}$ and $\mathrm{Mo}^{\mathrm{VI}}$ (Fig. 3C). For the reduced bulk catalyst sample, Mo K-edge X-ray absorption near-edge structure (XANES) spectroscopic 
analysis found the average valence of Mo to be 4.3 from the edge energy of $20011.7 \mathrm{eV}$ (Fig. 3D and fig. S9) (26). Fitting of the extended X-ray absorption fine structure (EXAFS) spectra found two major atomic shells for Mo-O $(1.99 \pm 0.03 \AA)$ and Mo-Mo $(2.57 \pm 0.02 \AA)$ (Fig. 3E, table S3, and fig. S10). This short Mo-Mo distance, in comparison to the value of $3.4 \AA$ in $\mathrm{Mo}^{\mathrm{VI}}$ oxide clusters (26), indicates the reduction of polymeric molybdate to $\mathrm{Mo}^{\mathrm{IV}}$ by Pd-activated $\mathrm{H}_{2}$ (19). The Mo-Mo coordination number $(\mathrm{CN}, 0.9 \pm 0.5)$ suggests the heterogeneity of the surface Mo species as a mixture of monomers $(\mathrm{CN}=0)$, dimers $(\mathrm{CN}=1)$, and polymers $(\mathrm{CN}>1)$.

Notably, the use of $\left(\mathrm{NH}_{2}\right)_{2}$ bpy ligand changed the structure and activity of $\mathrm{MoO}_{x}$ in the catalyst. Without the ligand, the $\mathrm{MoO}_{x}-\mathrm{Pd} / \mathrm{C}$ catalyst could not reduce $\mathrm{ClO}_{4}{ }^{-}$, and the highest $\mathrm{ClO}_{3}{ }^{-}$reduction was achieved with only $0.5 \mathrm{wt} \%$ of Mo (fig. S11). Thus, the additional $4.5 \mathrm{wt} \%$ of $\mathrm{Mo}$ in a $5 \mathrm{wt} \% \mathrm{MoO}_{x}-\mathrm{Pd} / \mathrm{C}$ catalyst acted as the structural building block of polymeric $\mathrm{MoO}_{x}$ clusters rather than catalytic sites. The $\mathrm{CN}$ for $\mathrm{Mo}-\mathrm{Mo}$ in $\mathrm{MoO}_{x}-\mathrm{Pd} / \mathrm{C}(1.7 \pm 0.6$, table S3) also indicated the dominance of polymeric $\mathrm{MoO}_{x}$ clusters (19). In stark comparison, the $\mathrm{ClO}_{4}{ }^{-}$ reduction activity of $\left[\left(\mathrm{NH}_{2}\right)_{2}\right.$ bpy $] \mathrm{MoO}_{x}-\mathrm{Pd} / \mathrm{C}$ showed a linear increase until reaching $5 \mathrm{wt} \%$ of Mo. Thus, most Mo atoms acted as catalytic sites, and the most probable structure is an oligomer with one $\left(\mathrm{NH}_{2}\right)_{2}$ bpy coordinating with each Mo (Fig. 2B). The elevated sensitivity with concentrated $\mathrm{Cl}^{-}$upon the use of $\left(\mathrm{NH}_{2}\right)_{2}$ bpy (table S2) also corroborates the altered structure of $\mathrm{MoO}_{x}$ by the organic ligand. A representative dimer structure (Fig. 3F) is proposed based on the reported crystal structure of $\mathrm{Mo}^{\mathrm{VI}}{ }_{2} \mathrm{O}_{6}\left[(t \mathrm{Bu})_{2} b p y\right]_{2}$, a byproduct from the hydrothermal reaction using $\mathrm{MoO}_{3}$ and 4,4'-(tBu$)_{2}$ bpy (27). Such a structure allows for multi-valent transformation of Mo between +VI and +II (Fig. 3B).

Scanning transmission electron microscopy (STEM) and energy dispersive X-ray spectrometry (EDS) element mapping images indicate the ubiquitous distribution of Mo and $\mathrm{N}$ on 
either carbon support or $\mathrm{Pd}^{0}$ nanoparticles (Figs. 3G-3J and figs. S12-S14). The poor EXAFS fittings including Mo-Pd bonding (table S4) suggest isolated aggregation and distinct roles of Mo sites (OAT for $\mathrm{ClO}_{\mathrm{x}}{ }^{-}$reduction) and $\mathrm{Pd}$ nanoparticles (electron transfer from $\mathrm{H}_{2}$ ). However, the hydrogenation reaction is necessary to transform the polymeric $\mathrm{Mo}^{\mathrm{VI}}$ precursors (19) and the free ligand into specific $\left[\left(\mathrm{NH}_{2}\right)_{2}\right.$ bpy $] \mathrm{MoO}_{x}$ structures to be reactive with $\mathrm{ClO}_{4}{ }^{-}$. For example, our cyclic voltammetry studies on the $\left[\left(\mathrm{NH}_{2}\right)_{2}\right.$ bpy $] \mathrm{MoO}_{x} / \mathrm{C}$ material (without $\mathrm{Pd}^{0}$ nanoparticles) between 0.37 and $-1.1 \mathrm{~V}$ (versus the reversible hydrogen electrode) did not observe $\mathrm{ClO}_{4}{ }^{-}$reduction (fig. S15) but instead showed the reduction peaks of $\mathrm{MoO}_{x}$ and $\left(\mathrm{NH}_{2}\right)_{2}$ bpy ligand (fig. S16). The potential allows the reduction of $\mathrm{Mo}^{\mathrm{VI}}$ into $\mathrm{Mo}^{\mathrm{V}}$, $\mathrm{Mo}^{\mathrm{IV}}$, and $\mathrm{Mo}^{\mathrm{III}}(28,29)$, but the $\left[\left(\mathrm{NH}_{2}\right)_{2}\right.$ bpy $] \mathrm{MoO}_{x}$ clusters formed from the electrochemical reduction (26) were probably in different structures and thus not reactive with $\mathrm{ClO}_{4}{ }^{-}$.

The rapid and robust $\mathrm{ClO}_{4}{ }^{-}$reduction by a series of $(\boldsymbol{L}) \mathrm{MoO}_{x}-\mathrm{Pd} / \mathrm{C}$ catalysts can be attributed to three major mechanisms similar to the microbial reduction process. First, the OAT energy barrier is lowered by the organic ligand (substituted bpy versus pterin in the Mo co-factor). Second, the redox cycling of Mo is sustained by the electron transfer from $\mathrm{H}_{2}$ (enabled by the $\mathrm{Pd}^{0}$ nanoparticle versus multiple biological metal factors). Third, the Mo-bound $\mathrm{ClO}_{4}{ }^{-}$requires the activation via protonation (externally added acid versus amino acid residues in the enzyme pocket). Mechanistic insights of this study highlight a strategy for designing bioinspired systems with common chemicals and simple approaches. Water-compatible heterogeneous catalyst systems will advance environmental and energy technologies for the removal and utilization of $\mathrm{ClO}_{4}{ }^{-}$. 


\section{Acknowledgments:}

Dr. Krassimir Bozhilov assisted STEM characterization at the Central Facility for Advanced Microscopy and Microanalysis (CFAMM) at UC Riverside. Dr. Ich Tran assisted XPS characterization at the UC Irvine Materials Research Institute (IMRI). Funding: UC Riverside startup grant and the National Science Foundation (NSF) Division of Chemical, Bioengineering, Environmental, and Transport Systems, Environmental Engineering Program (CBET-1932942) for C.R., E.B., J.P., and J.L.; the U.S. Department of Energy (DOE) Experimental Program to Stimulate Competitive Research (DOE-EPSCoR DE-SC0016272) for P.Y. and M.Z.; NSF Division of Chemistry, Chemical Catalysis Program (CHE-1566106) for J.S. and Y.W. The use of Stanford Synchrotron Radiation Lightsource at SLAC National Accelerator Laboratory was supported by the U.S. DOE, Office of Science, Office of Basic Energy Sciences (DE-AC0276SF00515). The XPS facility at IMRI was funded in part by NSF Major Research Instrumentation Program (CHE-1338173). Author contributions: C.R. and J.L. conceived and designed the project and wrote the manuscript; C.R., E.B., and J.P. carried out the experiments; P.Y. and M.Z. performed XANES and EXAFS characterization; J.S. and Y.W. performed electrochemical studies; and all authors analyzed the data and discussed the manuscript. Competing interests: The authors declare no competing interests. Data and materials availability: All data is available in the main text or the supplementary materials.

\section{Supplementary Materials:}

$20 \quad$ Materials and Methods

Supplementary Text

Figures S1-S16

Tables S1-S4

References (30-45) 


\section{References:}

1. B. Gu, J. D. Coates, Eds., Perchlorate: Environmental Occurrence, Interactions and Treatment (Springer Science \& Business Media, 2006).

2. P. Brandhuber, S. Clark, K. Morley, A review of perchlorate occurrence in public drinking water systems. J. Am. Water Works Assoc. 101, 63-73 (2009).

3. M. H. Hecht, S. P. Kounaves, R. C. Quinn, S. J. West, S. M. M. Young, D. W. Ming, D. C. Catling, B. C. Clark, W. V. Boynton, J. Hoffman, L. P. DeFlores, K. Gospodinova, J. Kapit, P. H. Smith, Detection of perchlorate and the soluble chemistry of martian soil at the Phoenix lander site. Science 325, 64-67 (2009).

4. W. A. Jackson, A. F. Davila, D. W.G. Sears, J. D. Coates, C. P. McKay, M. Brundrett, N. Estrada, J.K. Böhlke, Widespread occurrence of (per)chlorate in the Solar System. Earth Planet. Sci. Lett. 430, 470-476 (2015).

5. A. F. Davila, D. Willson, J. D. Coates, C. P. McKay, Perchlorate on Mars: a chemical hazard and a resource for humans. Int. J. Astrobiol. 12, 321-325 (2013).

6. J. D. Coates, L. A. Achenbach, Microbial perchlorate reduction: rocket-fuelled metabolism. Nat. Rev. Microbiol. 2, 569-580 (2004).

7. M. D. Youngblut, O. Wang, T. P. Barnum, J. D. Coates, (Per)chlorate in biology on earth and beyond. Annu. Rev. Microbiol. 70, 435-457 (2016).

8. G. Schwarz, R. R. Mendel, M. W. Ribbe, Molybdenum cofactors, enzymes and pathways. Nature 460, 839-847 (2009).

9. R. H. Holm, Metal-centered oxygen atom transfer reactions. Chem. Rev. 87, 1401-1449 (1987). 
10. M. D. Youngblut, C. L. Tsai, I. C. Clark, H. K. Carlson, A. P. Maglaqui, P. S. Gau-Pan, S. A. Redford, A. Wong, J. A. Tainer, J. D. Coates, Perchlorate reductase is distinguished by active site aromatic gate residues. J. Biol. Chem. 291, 9190-9202 (2016).

11. M. G. Bertero, R. A. Rothery, M. Palak, C. Hou, D. Lim, F. Blasco, J. H. Weiner, N. C. J. Strynadka, Insights into the respiratory electron transfer pathway from the structure of nitrate reductase A. Nat. Struct. Mol. Biol. 10, 681-687 (2003).

12. C. L. Ford, Y. J. Park, E. M. Matson, Z. Gordon, A. R. Fout, A bioinspired iron catalyst for nitrate and perchlorate reduction. Science 354, 741-743 (2016).

13. M. J. Drummond, T. J. Miller, C. L. Ford, A. R. Fout, Catalytic perchlorate reduction using iron: mechanistic insights and improved catalyst turnover. ACS Catal. 10, 3175-3182 (2020).

14. J. M. Hutchison, S. K. Poust, M. Kumar, D. M. Cropek, I. E. MacAllister, C. M. Arnett, J. L. Zilles, Perchlorate reduction using free and encapsulated Azospira oryzae enzymes. Environ. Sci. Technol. 47, 9934-9941 (2013).

15. L. T. Elrod, E. Kim, Lewis acid assisted nitrate reduction with biomimetic molybdenum oxotransferase complex. Inorg. Chem. 57, 2594-2602 (2018).

16. Y. B. Yin, S. Guo, K. N. Heck, C. A. Clark, C. L. Coonrod, M. S. Wong, Treating water by degrading oxyanions using metallic nanostructures. ACS Sustain. Chem. Eng. 6, 11160-11175 (2018).

17. B. P. Chaplin, M. Reinhard, W. F. Schneider, C. Schüth, J. R. Shapley, T. J. Strathmann, C. J. Werth, Critical review of Pd-based catalytic treatment of priority contaminants in water. Environ. Sci. Technol. 46, 3655-3670 (2012). 
18. O. F. Oyerinde, C. L. Weeks, A. D. Anbar, T. G. Spiro, Solution structure of molybdic acid from Raman spectroscopy and DFT analysis. Inorg. Chim. Acta 361, 1000-1007 (2008).

19. C. Ren, P. Yang, J. Gao, X. Huo, X. Min, E. Y. Bi, Y. Liu, Y. Wang, M. Zhu, J. Liu, Catalytic reduction of aqueous chlorate with $\mathrm{MoO}_{\mathrm{x}}$ immobilized on Pd/C. ACS Catal. 10, 8201-8211 (2020).

20. K. D. Hurley, Y. Zhang, J. R. Shapley, Ligand-enhanced reduction of perchlorate in water with heterogeneous Re-Pd/C catalysts. J. Am. Chem. Soc. 131, 14172-14173 (2009).

21. J. Liu, X. Chen, Y. Wang, T. J. Strathmann, C. J. Werth, Mechanism and mitigation of the decomposition of an oxorhenium complex-based heterogeneous catalyst for perchlorate reduction in water. Environ. Sci. Technol. 49, 12932-12940 (2015).

22. E. N. Mirts, I. D. Petrik, P. Hosseinzadeh, M. J. Nilges, Y. Lu, A designed heme-[4Fe-4S] metalloenzyme catalyzes sulfite reduction like the native enzyme. Science 361, 1098-1101 (2018).

23. M. M. Abu-Omar, L. D. McPherson, J. Arias, V. M. Béreau, Clean and efficient catalytic reduction of perchlorate. Angew. Chem. 112, 4480-4483 (2000).

24. Y. Zhang, K. D. Hurley, J. R. Shapley, Heterogeneous catalytic reduction of perchlorate in water with $\mathrm{Re}-\mathrm{Pd} / \mathrm{C}$ catalysts derived from an oxorhenium(V) molecular precursor. Inorg. Chem. 50, 1534-1543 (2011).

25. J. Liu, J. K. Choe, Y. Wang, J. R. Shapley, C. J. Werth, T. J. Strathmann, Bioinspired complexnanoparticle hybrid catalyst system for aqueous perchlorate reduction: rhenium speciation and its influence on catalyst activity. ACS Catal. 5, 511-522 (2015). 
26. H. Wang, S. Hamanaka, Y. Nishimoto, S. Irle, T. Yokoyama, H. Yoshikawa, K. Awaga, In operando X-ray absorption fine structure studies of polyoxometalate molecular cluster batteries: polyoxometalates as electron sponges. J. Am. Chem. Soc. 134, 4918-4924 (2012).

27. T. R. Amarante, P. Neves, F. A. A. Paz, M. Pillinger, A. A. Valente, I. S. Gonçalves, A dinuclear oxomolybdenum(VI) complex, $\left[\mathrm{Mo}_{2} \mathrm{O}_{6}(4,4 \text { '-di-tert-butyl-2,2'-bipyridine })_{2}\right]$, displaying the $\left\{\mathrm{MoO}_{2}(\mu-\mathrm{O})_{2} \mathrm{MoO}_{2}\right\}^{0}$ core, and its use as a catalyst in olefin epoxidation. Inorg. Chem. Commun. 20, 147-152 (2012).

28. N. Anbananthan, K. N. Rao, V. Venkatesan, Cyclic voltammetric investigations of the reduction of $\mathrm{Mo}(\mathrm{VI})$ to $\mathrm{Mo}(\mathrm{IV})$ in $1 \mathrm{M}$ sulphuric acid. J. Electroanal. Chem. 374, 207-214 (1994).

29. J. You, D. Wu, H. Liu, Electrochemical studies of molybdate and thiomolybdates. Polyhedron 5, 535-537 (1986).

30. S. I. Zabinsky, J. J. Rehr, A. Ankudinov, R. C. Albers, M. J. Eller, Multiple-scattering calculations of X-ray-absorption spectra. Phys. Rev. B 52, 2995-3009 (1995).

31. S. Ghasemi, S. R. Hosseini, S. Nabipour, P. Asen, Palladium nanoparticles supported on graphene as an efficient electrocatalyst for hydrogen evolution reaction. Int. J. Hydrog. Energy 40, 16184-16191 (2015).

32. L. D. McPherson, M. Drees, S. I. Khan, T. Strassner, M. M. Abu-Omar, Multielectron atom transfer reactions of perchlorate and other substrates catalyzed by rhenium oxazoline and thiazoline complexes: reaction kinetics, mechanisms, and density functional theory calculations. Inorg. Chem. 43, 4036-4050 (2004). 
33. S. Ainsworth, Michaelis-Menten kinetics in Steady-State Enzyme Kinetics. (Macmillan Education UK, London, 1977), pp. 43-73.

34. D. Shuai, J. K. Choe, J. R. Shapley, C. J. Werth, Enhanced activity and selectivity of carbon nanofiber supported Pd catalysts for nitrite reduction. Environ. Sci. Technol. 46, 2847-2855 (2012).

35. P. B. Weisz, C. D. Prater, Interpretation of measurements in experimental catalysis. Adv. Catal. 6, 143-195 (1954).

36. C. N. Satterfield, Mass Transfer in Heterogeneous Catalysis (MIT Press, Cambridge, MA, 1970).

37. M. G. Davie, M. Reinhard, J. R. Shapley, Metal-catalyzed reduction of Nnitrosodimethylamine with hydrogen in water. Environ. Sci. Technol. 40, 7329-7335 (2006).

38. S. R. Heil, M. Holz, T. M. Kastner, H. Weingärtner, Self-diffusion of the perchlorate ion in aqueous electrolyte solutions measured by ${ }^{35} \mathrm{Cl}$ NMR spin-echo experiments. J. Chem. Soc. Faraday Trans. 91, 1877-1880 (1995).

39. P. Sänger, W.-D. Deckwer, Liquid — solid mass transfer in aerated suspensions. Chem. Eng. J. 22, 179-186 (1981).

40. Y. Sano, N. Yamaguchi, T. Adachi, Mass transfer coefficients for suspended particles in agitated vessels and bubble columns. J. Chem. Eng. Japan 7, 255-261 (1974).

41. R. L. Bates, P. L. Fondy, R. R. Corpstein, Examination of some geometric parameters of impeller power. Ind. Eng. Chem. Process. Des. Dev. 2, 310-314 (1963). 
42. B. Liu, H. Yao, W. Song, L. Jin, I. M. Mosa, J. F. Rusling, S. L. Suib, J. He, Ligand-free noble metal nanocluster catalysts on carbon supports via "soft" nitriding. J. Am. Chem. Soc. 138, 4718-4721 (2016).

43. K. D. Hurley, J. R. Shapley, Efficient heterogeneous catalytic reduction of perchlorate in water. Environ. Sci. Technol. 41, 2044-2049 (2007).

44. J. Liu, M. Han, D. Wu, X. Chen, J. K. Choe, C. J. Werth, T. J. Strathmann, A new bioinspired perchlorate reduction catalyst with significantly enhanced stability via rational tuning of rhenium coordination chemistry and heterogeneous reaction pathway. Environ. Sci. Technol. 50, 5874-5881 (2016). the stability and activity of $\mathrm{Re} / \mathrm{Pd}$ bimetal catalysts used for perchlorate reduction. Environ. Sci. Technol. 44, 4716-4721 (2010). 


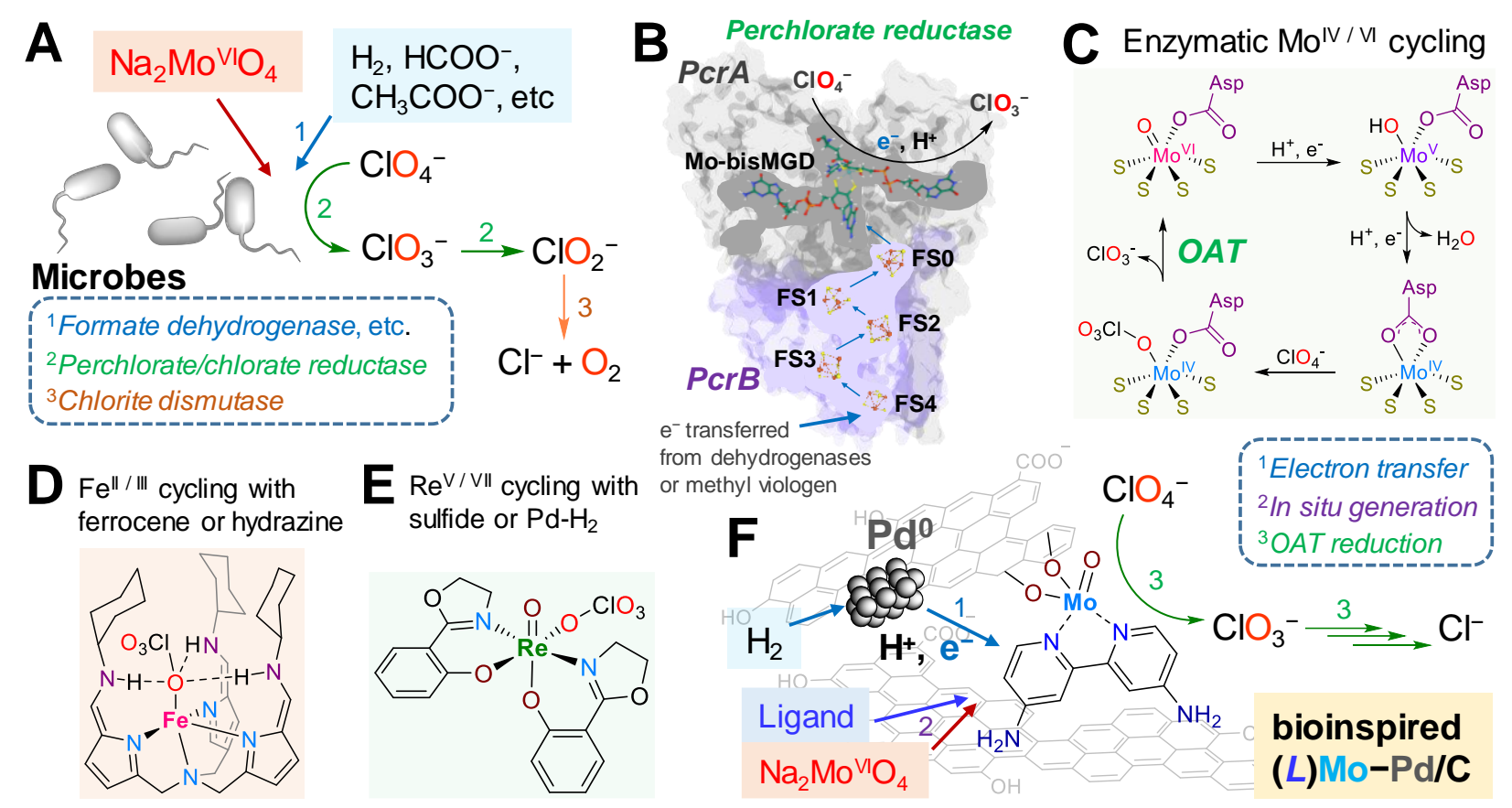

Fig. 1. Comparison of microbial and abiotic systems for perchlorate reduction. (A) Microbial process for $\mathrm{ClO}_{4}{ }^{-}$reduction; (B) electron transfer and metal centers in perchlorate reductase (Pcr); (C) proposed redox cycling of the Mo co-factor in reference (10); (D) a reported bioinspired iron 5 complex for $\mathrm{ClO}_{4}{ }^{-}$reduction; (E) a reported rhenium complex for $\mathrm{ClO}_{4}{ }^{-}$reduction; $(\mathbf{F})$ the general working mechanism of the new $(\boldsymbol{L}) \mathrm{MoO}_{x}-\mathrm{Pd} / \mathrm{C}$ catalyst in this study. 

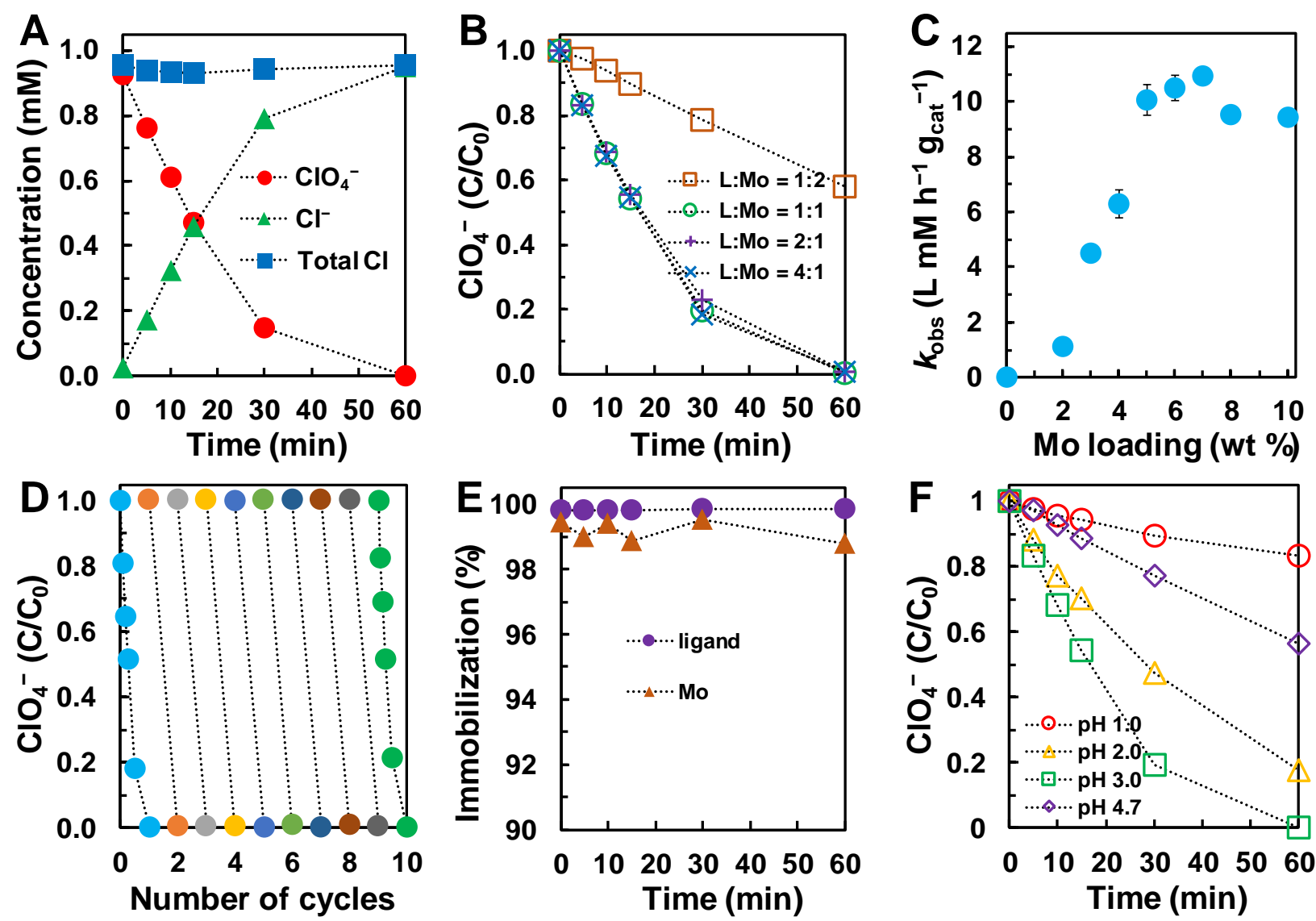

Fig. 2. Kinetics data. (A) Chlorine balance during the reduction of $\mathrm{ClO}_{4}^{-}$; (B) the effect of the different molar ratios of $\left(\mathrm{NH}_{2}\right)_{2}$ bpy:Mo; $(\mathbf{C})$ the effect of Mo content in the catalyst (y-axis: apparent $0^{\text {th }}$-order rate constant divided by the catalyst loading); (D) performance for ten spikes of $1 \mathrm{mM} \mathrm{ClO}_{4}^{-} ;(\mathbf{E})$ the ratio of immobilized ligand and Mo during the reduction of $\mathrm{ClO}_{4}^{-} ;(\mathbf{F})$ the effect of solution $\mathrm{pH}$. Default reaction conditions: $0.2 \mathrm{~g} \mathrm{~L}^{-1}$ catalyst (5 wt $\%$ Mo in $5 \mathrm{wt} \% \mathrm{Pd} / \mathrm{C}$, molar ratio of $\left(\mathrm{NH}_{2}\right)_{2}$ bpy:Mo=1:1), $1 \mathrm{mM} \mathrm{ClO}_{4}^{-}$, $\mathrm{pH} \mathrm{3.0,1} \mathrm{atm} \mathrm{H}_{2}, 20^{\circ} \mathrm{C}$. 

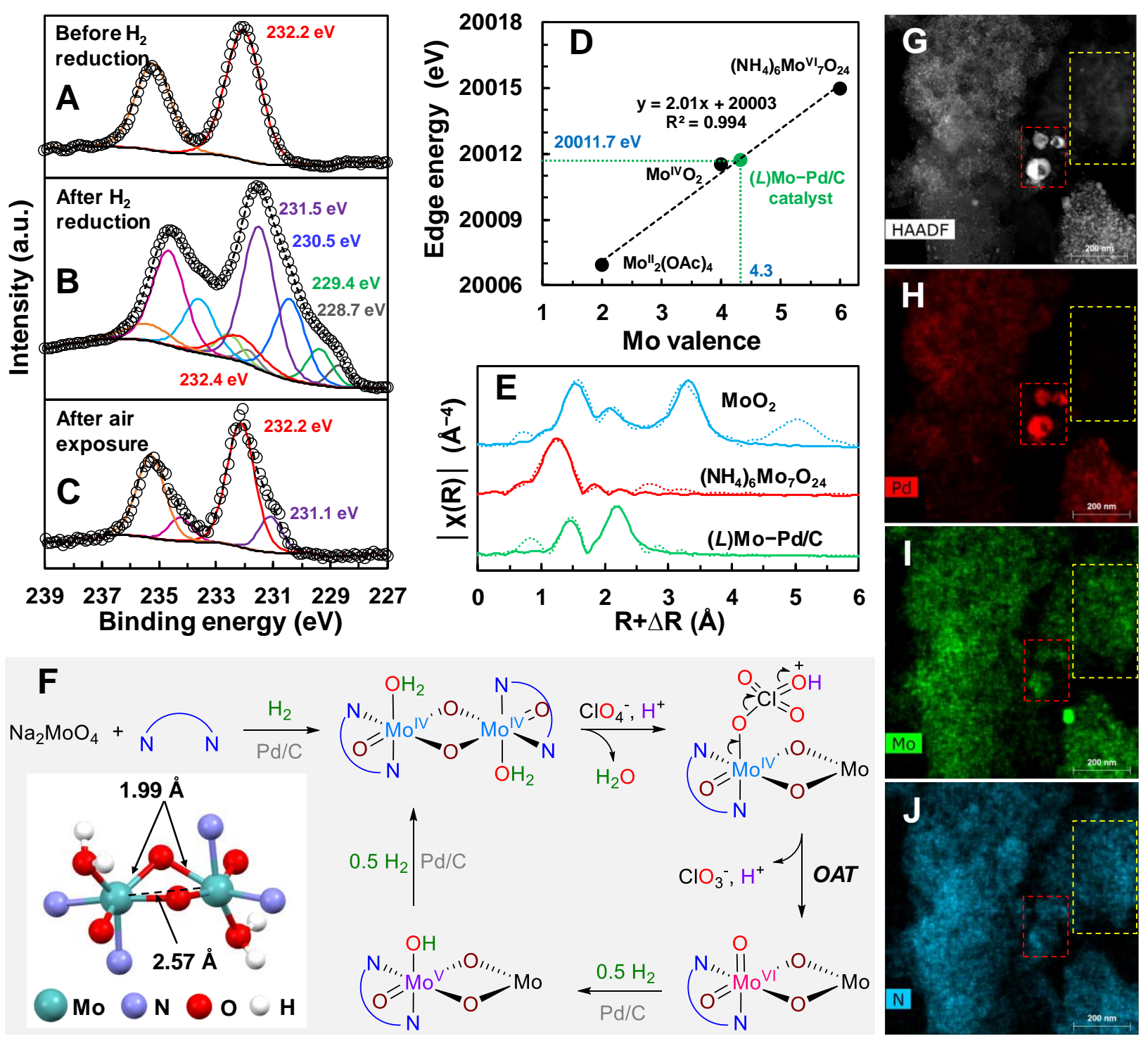

Fig. 3. Characterization data and proposed reaction mechanisms. (A-C) Mo 3d XPS spectra (empty dots) and fits (solid lines) of the $\left[\left(\mathrm{NH}_{2}\right)_{2}\right.$ bpy] $\mathrm{MoO}_{x}-\mathrm{Pd} / \mathrm{C}$ catalyst; $(\mathbf{D})$ the correlation between Mo K-edge XANES energies and valences for the catalyst and Mo references; (E) the

EXAFS Fourier transforms (dotted lines) and their fits (solid lines); (F) a proposed structure of the reduced $\left[\left(\mathrm{NH}_{2}\right)_{2}\right.$ bpy] $\mathrm{MoO}_{x}$ species and one representative redox transformation for the catalytic reduction of $\mathrm{ClO}_{4}^{-} \cdot(\mathbf{G}-\mathbf{J})$ HAADF-STEM imaging of the $\left[\left(\mathrm{NH}_{2}\right)_{2}\right.$ bpy $] \mathrm{MoO}_{x}-\mathrm{Pd} / \mathrm{C}$ catalyst and EDX mapping of $\mathrm{Pd}, \mathrm{Mo}$, and $\mathrm{N}$. The two dotted areas show the heterogeneity of $\left[\left(\mathrm{NH}_{2}\right)_{2} b p y\right] \mathrm{MoO}_{\mathrm{x}}$ species immobilized on both carbon support and Pd particles. 
Table 1. Perchlorate Reduction Activity of Mo-Pd/C Catalysts Enabled by Various Nitrogen

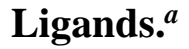

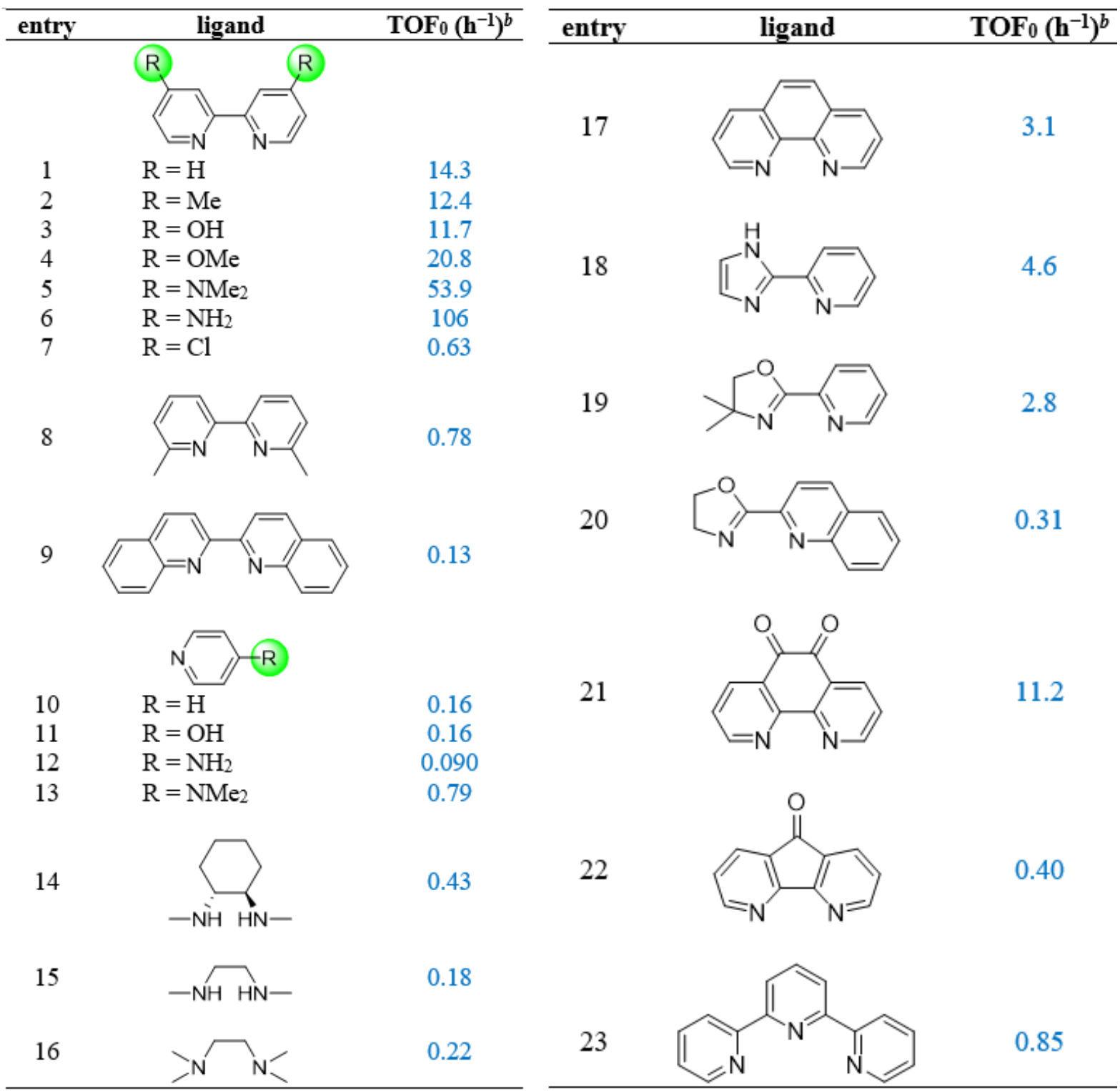

${ }^{a}$ Reaction conditions: $1 \mathrm{mM} \mathrm{ClO}_{4}^{-}$in water, $0.5 \mathrm{~g} \mathrm{~L}^{-1}$ catalyst (5 wt\% Mo and $5 \mathrm{wt} \% \mathrm{Pd}$ on carbon), molar ratio of Ligand:Mo $=1$ (bidentate) or 2 (monodentate), $\mathrm{pH} 3.0,1 \mathrm{~atm} \mathrm{H}_{2}, 20^{\circ} \mathrm{C}$. Entries 5 and 6 used $0.2 \mathrm{~g} \mathrm{~L}^{-1}$ catalyst.

${ }^{b}$ Calculated using the degradation of the first $5 \%$ of $1 \mathrm{mM} \mathrm{ClO}_{4}{ }^{-}$and four OAT cycles to reduce each $\mathrm{ClO}_{4}^{-}$into $\mathrm{Cl}^{-}$. 